\title{
学界情報
}

\section{Asia-Pacific Power and Energy Engineering Conference (APPEEC2012) 報告}

\author{
渡邊 政幸（九州工業大学）
}

\section{1. はじめに}

APPEEC (Asia-Pacific Power and Energy Engineering Conference）は 2009 年開始の電力・エネルギー分野に関す る国際会議であり，第 4 回会議 APPEEC2012 が中国上海 において 2012 年 3 月 27 日から 29 日まで開催された。上 海はご存じのとおりの国際都市であり，世界各国からの注 目が集まっている。揚子江の河口に位置し，中国東部にお ける経済・金融・貿易・文化，科学技術の中心であり，観 光も盛んである。上海の多文化性によって独特の魅力があ り，伝統的なものから近代のものまで，西洋東洋織りまぜ た文化の融合をうまく果たしている。近年の目覚ましい発 展とともに超高層ビルと旧来の石庫門（上海を代表する伝 統的民家建築）が同居し，西洋の風習と中国の伝統が結び ついて訪れたものを魅了している。

本会議は IEEE Power \& Energy Society（PES）をは じめとして，他にも上海交通大学，武漢大学，同済大学， 天津大学, 江蘇大学, 華中科技大学, 北京航空航天大学, 華北電力大学, 南京工業大学, 華東理工大学, 廣西大学, 中国石油大学，上海大学といった多数の大学の協賛により 開催された。

\section{2. 会議の概要}

多くは中国からの参加であったが，日本，タイ，マレー シア，イラン，インド，米国，英国などからの参加も多く 見られた。

会議では，4 件の Plenary Speech，18 の Oral セッション (論文数は 252 件), 5 のポスターセッション（論文数は 934 件) が開催された。セッション構成は, Power Transmission and Distribution, Power System Analysis and Optimization, Modeling, Simulation and Stability Control for Power System といった従来からあるテーマから,

Smart Grid, Safe Nuclear Energy and Photovoltaic, Wind Power Technologies, Bio-energy and Fuel from Waste Products, New Technologies for Energy Efficiency といった近年特に検討が進んでいるテーマも多く含んで構 成されていた。英語での発表がはじめてと思われる学生に よる発表も多く見られた。

Plenary Speech において, IEEE PES 部門長である Noel Schulz 教授により，“Beyond Blackouts and Natural Disasters: Recovery and Advancements for A Smarter Grid for the Future” の演題で講演が行われた（図 1)。各 国における大停電や大規模自然災害からの復旧事例の紹介 とともに，米国や IEEE におけるスマートグリッドの取り 組み, IEEE PES の紹介などが行われた。講演のなかで

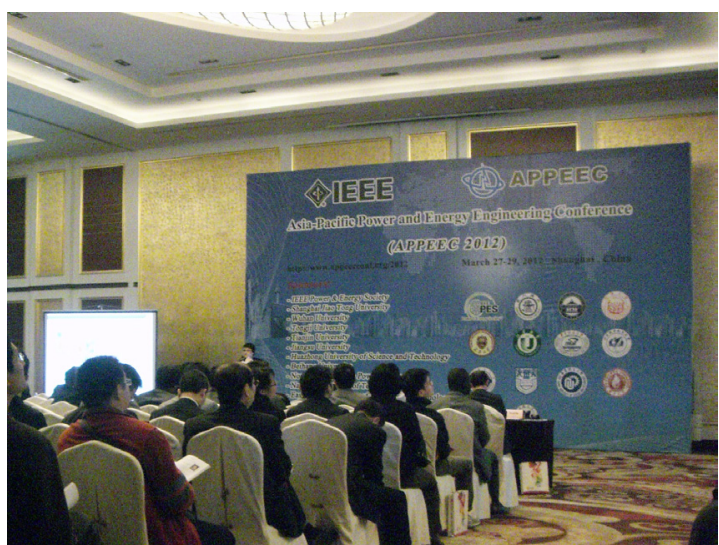

図 1 Schulz 教授の講演

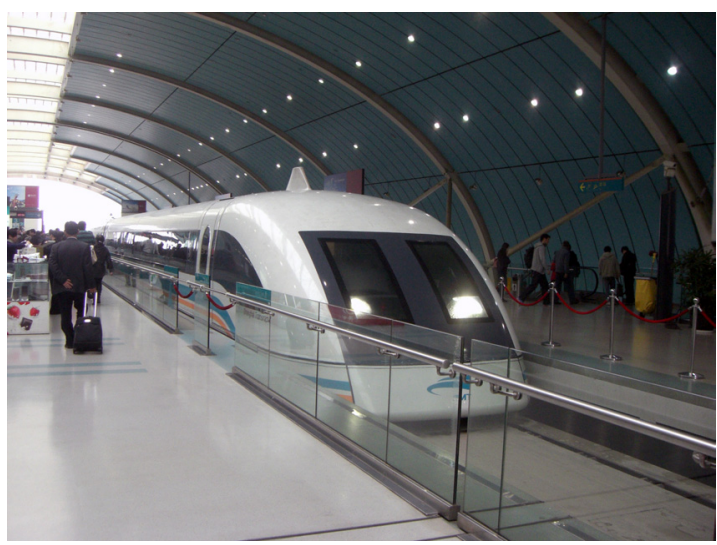

図 2 上海トランスラピッド（竜陽路駅） 営業最高速度は $430 \mathrm{~km} / \mathrm{h}$

$\lceil$ your personal smart network」という言葉が印象に残り， 研究者・技術者間の交流が重要であることはもちろんであ るが，電力を取り巻く環境になぞらえて各国が協力して大 きな諸課題に取り組む必要性を改めて認識した。

4 件の Plenary Speech のうち，3 件がスマートグリッド 関連の話題であり，聴講者の関心もかなり高かったように 思われる。1 件は HVDC（直流送電）に関する講演で，国土 が広大でかつ電力需要増加の著しい中国においては重要な 課題であり, UHV 送電とあわせて今後の展開が注目される。

3. おわりに

次回, APPEEC2013 は中国北京において 2013 年 3 月 24 日から 27 日の日程で開催予定である。公式 Web サイトは http://www.appeecconf.org/2013/である。日本からも多数参 加されることを期待する。

(2012 年 5 月 4 日受付) 